\title{
Leucocyte Platelet Rich Fibrin with Autologous Gingival Fibroblasts in the Treatment of Adjacent Recession Defects
}

\author{
Fibrina Rica en Plaquetas Leucocitarias con Fibroblastos Gingivales \\ Autólogos en el Tratamiento de Defectos de Recesión Adyacentes
}

\author{
Gabriel Merizalde ${ }^{1,2}$; Daniela Lopera1; Mauricio Villegas ${ }^{3}$ \& Luz Marina Restrepo ${ }^{1,2}$
}

MERIZALDE, G.; LOPERA, D.; VILLEGAS, M. \& RESTREPO, L. M. Leucocyte platelet rich fibrin with autologous gingival fibroblasts in the treatment of adjacent recession defects. Int. J. Odontostomat., 13(1):23-30, 2019.

\begin{abstract}
Periodontium can submit changes that lead to loss of integrity, such as periodontal disease, immune disorders or traumatic brushing. One of the most common consequences resulting from these events is the apical migration of gingival marginal tissue. Among biomaterials used for periodontal tissue regeneration, fibrin matrices have received significant attention to correct gingival recessions. Five oral mucosa biopsies were extracted, fibroblasts were in vitro cultured and frozen in liquid nitrogen. Three $10 \mathrm{~mL}$ glass sterile tubes were filled with patient blood and centrifuged immediately; clots were extracted and compressed to obtain L-PRF membranes. Autologous oral mucosa fibroblasts were added to the membranes and surgical procedures were performed in five patients. L-PRF fibrin network pore size was too small to allow human fibroblasts penetration but they were firmly attached to membrane surface. Gingival fibroblasts from fresh cell culture and recently thawed were used to attach on the L-PRF membranes. It was possible to establish a protocol for blood collection, centrifugation, fibrin clot compression, fibroblast adhesion to the membrane surface and patient application in a relatively short time (1 hour-1 hour and 30 minutes). Two patients expressed pain symptoms and the other ones presented light swelling without pain. In the first week, adjacent tissue showed few inflammation signs. Research efforts are being conducted to develop more conservative surgical techniques and new biomaterials that can promote cellular proliferation. Because of its properties, L-PRF membranes represent a tempting alternative. A combined technique to treat adjacent recession defects with L-PRF membranes and autologous oral mucosa fibroblasts in a coronal displaced flap did not show initial advantage compared with a gold standard surgery that includes an autologous soft tissue graft. Nevertheless, it could be an alternative for clinical application as a new functional cell biomaterial. More clinical evidence is needed.
\end{abstract}

KEY WORDS: fibrin, periodontium, fibroblasts, wound healing, gingival recession.

\section{INTRODUCTION}

Periodontium can submit changes that lead to loss of integrity, such as periodontal disease, burns, allergies, immune disorders or traumatic brushing (Feng \& Weinberg, 2006). One of the most common consequences resulting from the above events is the apical migration of gingival marginal tissue or gingival recession. This positional change of the mucosa inevitably exposed root surface and brings unpleasant consequences such as difficult to remove food debris, loss of supporting tissues and dentinal hypersensitivity (Pini Prato, 1999). Miller (1985) classified gingival recession into four categories by its extension to the mucogingival line and the integrity of the interproximal tissues, gingival recession Class I and Class II Miller do not present loss of interproximal integrity that is why they are feasible situations to improve.

A lot of techniques have been defined to correct gingival recessions looking for root coverage, increasing keratinized mucosa or to avoid future gingival deformities (Buti et al., 2013). It has been described that the best technique to achieve root coverage is the coronally advanced flap with a subepithelial palatal grafting (connective tissue). For restoring keratinized mucosa, the best option is an epithelized free graft or a subepithelial free graft. The

\footnotetext{
${ }^{1}$ Facultad de Medicina, Grupo Ingeniería de Tejidos y Terapias Celulares, Universidad de Antioquia, Medellín, Colombia.

${ }^{2}$ Laboratorio Terapia Celular y Biobanco, IPS Universitaria, Medellín, Colombia.

${ }^{3}$ Servicio de periodoncia, IPS Universitaria, Medellín, Colombia.
} 
preferred site for harvesting soft tissue grafts is the palate which requires a second surgical site, increasing morbidity in terms of procedure time, post-operative discomfort, delayed wound healing, bone necrosis, profuse bleeding during and after surgery, permanent paresthesia or anesthesia on the palate and severe pain after surgery (Sonick \& Hwang, 2011).

Currently, tissue engineering biomaterials are being used as a replacement for palatal tissue harvest, with the aim of reducing morbidity. Among the biomaterials used for periodontal tissue regeneration, fibrin matrices have received significant attention (Tobita \& Mizuno, 2013). Fibrin clot traps circulating stem cells that reach the site of injury at the initial neovascularization. Fibrin matrix guide covers damaged tissues, affecting epithelial and fibroblasts metabolism. Growth factors, particularly PDGF and TGF- $\beta$ with fibrin clot matrix proteins and fibronectin, probably stimulate fibroblast proliferation from tissue around wound, expression of integrin receptors and migration into the wound space (Clark, 2001). After migration and fibrin degradation, fibroblasts begin collagen synthesis (Choukroun et al. 2006a).

Leucocyte-Platelet Rich Fibrin (L-PRF) is a new biomaterial developed by Choukroun et al. (2001). It is a second generation of platelet concentrates, widely used to accelerate healing of hard and soft tissues mainly in dentistry. L-PRF is a fibrin network containing cytokines, structural glycoproteins (fibronectin), and glycosaminoglycans (heparin and hyaluronic acid). These biochemical components have well known effects on wound healing processes (Toffler et al., 2009; Dohan Ehrenfest et al., 2010).

Among its advantages over traditional PRP (Platelet Rich Plasma), L-PRF preparation is easy and low cost because it does not require bovine thrombin, calcium chloride, anticoagulant or biochemical modifications (Toffler et al.). L-PRF protocol allows platelet aggregation and cytokines release in a fibrin clot. It can be used directly as a clot or after it's compression as a resistant membrane (Toffler et al.; Dohan Ehrenfest et al.). Whole blood is placed into glass tubes without anticoagulant and centrifuged immediately. In a few minutes the absence of anticoagulant allows sample platelets activation and coagulation cascade initiation. A fibrin clot is obtained and removed from the tube. The L-PRF is placed on a special box (PRF box) and covered with the compressor. This produces an autologous fibrin membrane of constant thickness, which remains hydrated for several hours. Platelets are a rich source of polypeptide growth factors that can promote wound healing (Danielsen et al., 2008). Although platelets and leukocyte cytokines play an important role in L-PRF biology, fibrin matrix that supports them constitutes a decisive factor for the real therapeutic potential of this biomaterial (Toffler et al.).

The use of L-PRF membranes has already been evaluated in the correction of mucogingival defects and showed satisfactory results in some cases. In this study we intended to evaluate the behavior of L-PRF membrane with functionalized autologous fibroblasts on its surface, and to observe if this new technique favors root coverage and correct mucogingival recessions.

The aim of the research was to evaluate whether autologous fibroblasts from oral mucosa can be included or attached to the L-PRF membranes, and thereby, if it is possible to increase biomaterial performance to treat Miller recession class I, II and III defects.

\section{MATERIAL AND METHOD}

Oral Mucosa Biopsy Procedure and Cell Culture: After singing informed consent approved by the Bioetic committee from the University of Antioquia Medicine Faculty, five oral mucosa biopsies were taken at the periodontal service from the IPS Universitaria. Oral mucosa fibroblasts manipulation protocol (extraction, optimal size biopsy, disinfection, transportation, culture, freezing and thawing) was achieved. Fibroblasts were cultured in DMEM (Lonza) supplemented with $10 \%$ fetal bovine serum (FBS) and PEST (penicillinstreptomycin $1.000 \mathrm{UI} / 1.000 \mu \mathrm{g} / \mathrm{mL}$ ) in 25 and $75 \mathrm{~cm}^{2}$ culture dishes. Fibroblast subculture and expansion was performed and several cryogenic vials were frozen at $-196{ }^{\circ} \mathrm{C}$ in liquid nitrogen. L-PRF autologous fresh membranes were loaded with fresh and thawed mucosa fibroblasts and were placed in periodontal gingival deformities.

L-PRF Preparation and Cell Seeding: The application day, three $10 \mathrm{~mL}$ glass sterile tubes without anticoagulant were filled with patient blood. They were centrifuged immediately during ten minutes at 3.000 RPMs to form L-PRF fibrin clots. Clots were extracted and placed three minutes in the PRF-Box to be compressed to obtain membranes. L-PRF membranes were placed in $3 \mathrm{~mL}$ plastic Fisher tubes. Thawed or 
fresh autologous oral mucosa fibroblasts were added on $2 \mathrm{~mL}$ Ringer lactate solution and placed 30 minutes on an orbital agitator at $37{ }^{\circ} \mathrm{C}$ and $5 \% \mathrm{CO}_{2}$. After several trials, it was the minimum time that enable fibroblasts adherence to the membrane surface. LPRF membranes with autologous oral mucosa fibroblasts were sent to the periodontia service in sterile conditions in order to be applied on patients with multiple gingival recessions at the buccal side of mandibular teeth.

At the beginning, we tried to insert fibroblasts injecting them with an insulin syringe directly into the L-PRF membrane; but it did not work as we expected. Adherence to the membrane surface was demonstrated later. Some of the test membranes were fixed with $(10 \%)$ buffered formalin and then cross sections of L-PRF were stained with Hematoxilin/ Eosin (H/E).

Scanning Electron Microscopy (SEM): For ultrastructural analysis, L-PRF membranes with autologous oral mucosa fibroblasts were fixed in a $2.5 \%$ glutaraldehyde solution containing $0.085 \mathrm{M}$ cacodylate buffer for $1 \mathrm{~h}$. All samples were dehydrated through a graded series of ethanol and were eventually stored at $4{ }^{\circ} \mathrm{C}$. After critical point drying, samples of material were sputter-coated with (Hommur V) gold and analyzed using a scanning electron microscope (JEOL) at various magnifications.

Surgical Technique: Five patients were intervened. Local anesthesia with lidocaine $2 \%$ and epinephrine 1:80000 was used. A partial thickness flap with horizontal incision (including two anterior and posterior teeth) was lifted up to displace the soft tissue coronally. Papillary mucosa that is not maintained in the flap was de-epithelialized according to the technique described by Zucchelli \& De Sanctis (2000). After that, it was necessary root planning with curettes over the exposed root surfaces. Two L-PRF membranes were fixed with nonabsorbable nylon suture (ETHICON® Sylk Suture 5: 0), then the flap was displaced to cover them and it was sutured. Finally, the tissue was gently pressed about five minutes to allow direct contact between the periosteum and the fibrin membranes. Protocol for pain management after surgery included nonsteroidal ant inflammatory drugs (NSAIDs) over three days.

Clinical Evaluation: Measuring of Gingival Recession: For the measurement of the gingival recession, two anatomical reference points as the distance from the gingival margin to the CEJ (cement- enamel junction) were used, width of the attached gingiva, distance between the gingival margin and the mucogingival line. Clinical parameters such as probing depth, plaque index, bleeding on probing and clinical attachment level were considered. Measurements were performed before surgery, and after 3 and 6 months of tracing. All participants were informed through informed consent about advantages and disadvantages of the procedure.

\section{RESULTS}

After several attempts to inject L-PRF membranes with oral mucosa fibroblasts we could clearly established that oral mucosa fibroblasts only adhere to the L-PRF membrane surface. L-PRF fibrin network pore size was too small (about $1 \mu$ ) while average size of human fibroblast is about $17 \mu$. Oral mucosa fibroblast adhesion on the L-PRF membrane surface was demonstrated by different techniques as it can see in Figures 1 and 2. Oral fibroblasts from fresh cell culture and recently thawed were used to attach on the L-PRF membranes. The evidence of oral mucosa human fibroblast adherence on the surface of an autologous L-PRF membrane for potential clinical applications in dentistry is an innovative contribution to the use of L-PRF.

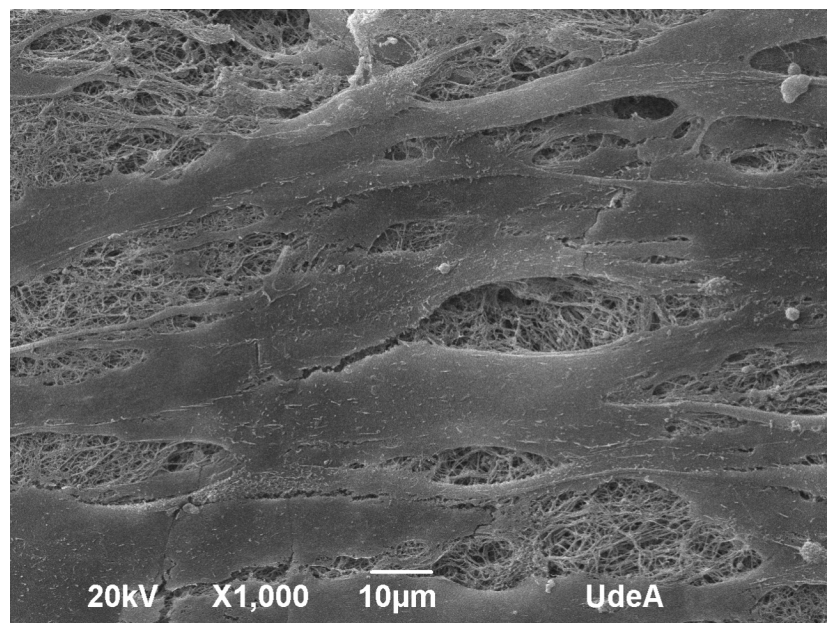

Fig. 1. Gingival Mucosa Fibroblast adhered to the L-PRF surface.

To promote the use of L-PRF membranes alone or with autologous fibroblasts, two of the most important commercial factors are: how long the process may take between patient blood sample, membrane production, fibroblast membrane adhesion and surgical site 


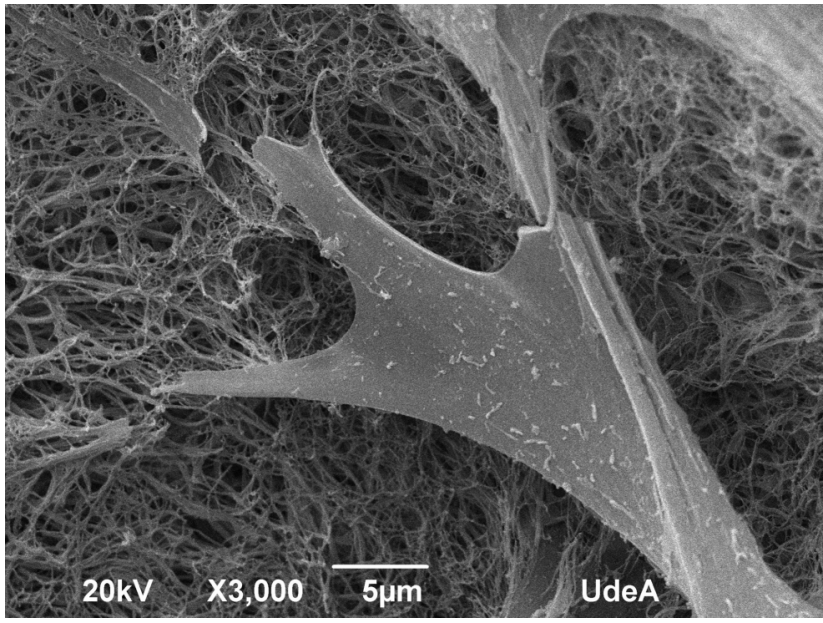

Fig. 2. Gingival mucosa fibroblast adhered to the L-PRF surface.

application, and finally, the cost. Requirements are particularly demanding. To obtain three $3 \mathrm{~cm}^{2}$ membranes of L-PRF after PRF-BOX compression, patient blood sample should be taken into three 10 $\mathrm{mL}$ tubes without anticoagulants and centrifuged immediately. The "in vitro" cultivated and expanded autologous fibroblasts previously frozen, should be thawed quickly and adding on a suitable medium to ensure viability conditions and membrane surface adhesion in short time to be transferred to the patient. It is important to note that it is not possible to freeze membranes for preservation; L-PRF membranes should be applied at least 3 hours after centrifugation and compression.

In this study, it was possible to establish a protocol for blood collection, centrifugation, fibrin clot compression, fibroblast adhesion to the membrane surface (in culture or thawed), and patient application in a relatively short time (1 hour- 1 hour and thirty). Five oral mucosa biopsies from the IPS Universitaria periodontal service, presented fibroblast proliferation and in vitro cell culture expansion. They were frozen in liquid nitrogen at $-196{ }^{\circ} \mathrm{C}$, thawed at $37^{\circ} \mathrm{C}$, added to the L-PRF membrane and subsequently applied to patients.

Clinical Results: Surgical technique was carried out on five patients. Two patients expressed pain symptoms in the first week after surgery and the other ones presented light swelling without pain. In the first week, the tissue showed few inflammation signs; one patient evidenced an extra oral edema solved 6 days after. The following are the clinical results of each patient undergoing surgery.
Case 1: In this case surgical technique started with a crestal incision in the edentulous area of 36 tooth and intrasulculars incisions in 35, 34, and 37 teeth for superficial mucosal flap preparation. The initial measurement of the gingival margin position for tooth 35 was $3 \mathrm{~mm}$. After 6 months the result is $1 \mathrm{~mm}$ of coverage at the margin midpoint. Keratinized mucosa showed an initial measurement of $2 \mathrm{~mm}$ and remained stable at 3 and 6 months.

Case 2: Incisions were made in 33, 34, 35 and 36 teeth for flap preparation. The initial gain is $3 \mathrm{~mm}$ at 3 months, passing from a $5 \mathrm{~mm}$ gingival recession at its most apical point to a measurement of $2 \mathrm{~mm}$. There was a gingival margin loss of $1 \mathrm{~mm}$ at 6 months in relation to 3 months, ending at $3 \mathrm{~mm}$ from the AUC. The amount of keratinized mucosa is stable in $1 \mathrm{~mm}$ during the 6 months period (Figs. 3, 4 and 5).

Case 3: Mucosal flap was prepared from 32 to 42 teeth. The 41 tooth area presented a mucogingival deformity Miller type III recession of $1 \mathrm{~mm}$, it was perforated 2 $\mathrm{mm}$ at flap reflection time. Final healing at 6 months showed a $1 \mathrm{~mm}$ increase in the gingival margin final position to $2 \mathrm{~mm}$ of the UAC. The tooth 31 had a measurement of the MG - UAC of $5 \mathrm{~mm}$ at the beginning, $2 \mathrm{~mm}$ at the most apical point of the margin at 3 months and $3 \mathrm{~mm}$ at 6 months. Keratinized mucosa presented $1 \mathrm{~mm}$ stability during the 6 months.

Case 4: Flap design was conceived to cover tooth 43, incisions included 41,42 and 44 tooths. The position of the MG-UAC was not modified after the 6 months procedure. Clinical changes were present in the keratinized mucosa, there was loss of tissue in the measurement after surgery; 0 measurements had 1 $\mathrm{mm}$ and at 6 months it was not possible to identify that type of mucosa.

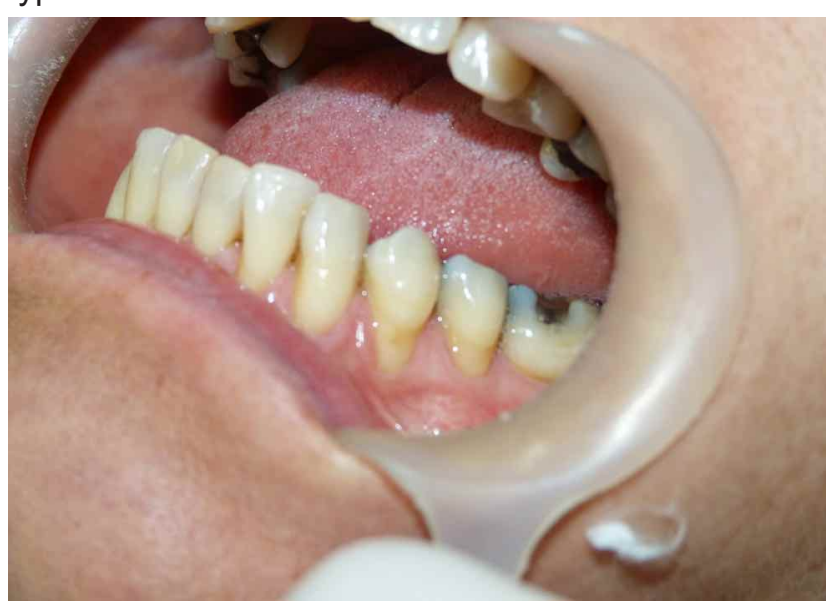

Fig. 3. Gingival recession located 33 and 34 buccal surfaces. 


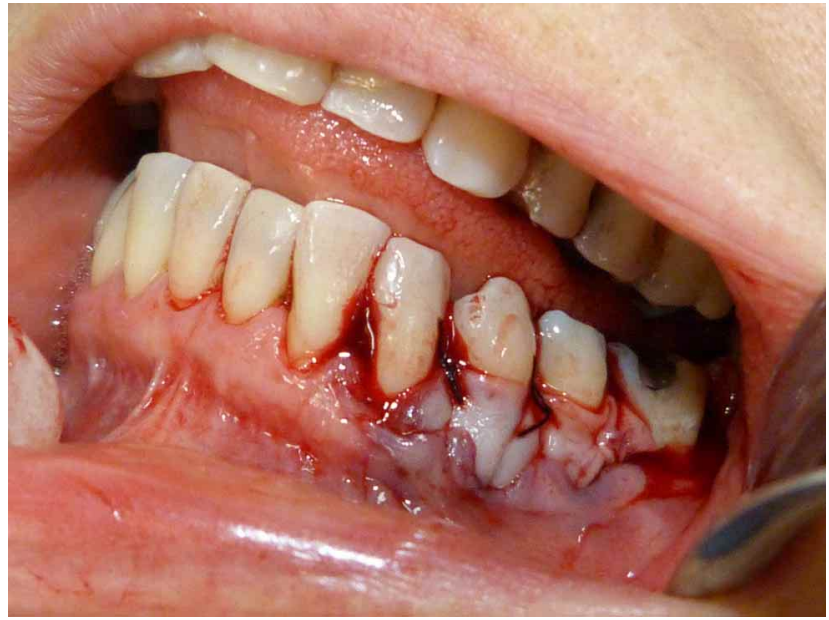

Fig. 4. L-PRF membranes placed on gingival recession.

Case 5: In this case, surgical technique included tooth 11 with type III Miller gingival recession of $7 \mathrm{~mm}$ vestibular at its most apical point. A cover of $4 \mathrm{~mm}$ of the root surface was seen at 3 months and it was reduced to $3 \mathrm{~mm}$ of coverage at 6 months, ending with an MG-UAC distance of $4 \mathrm{~mm}$. Unlike other cases, patient had a thick periodontium and still did not present changes.

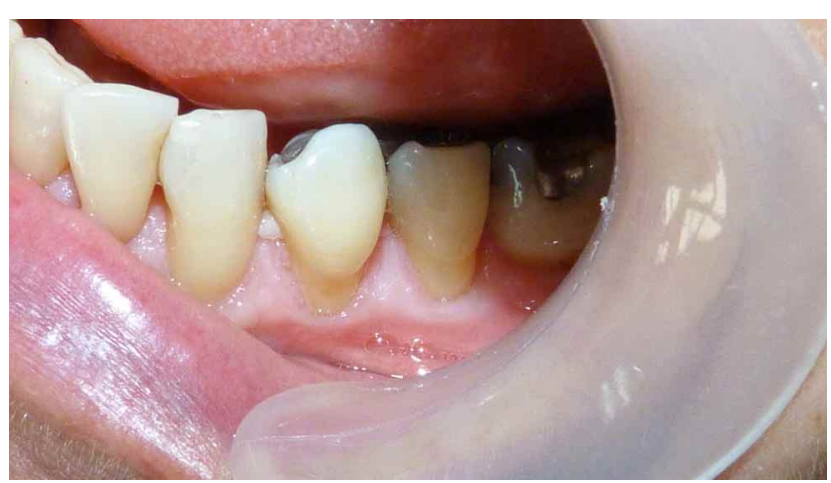

Fig. 5. Clinical appearence six months after surgery.

\section{DISCUSSION}

Complete root coverage is the biggest challenge of any surgical technique used at present in periodontal plastic surgery (Thoma et al., 2009). In a review, Ramachandra et al. (2014), presented possible complications associated when classic palatal and free gingival graft technique was applied and how this procedure is rejected by several patients. Throughout their work, they finally propose various alternatives for soft tissue grafts with newer techniques and also with new biomaterials that can promote cellular proliferation to enhance wound healing process. According to this, L-PRF membranes represent a tempting and logical alternative because of its different properties. Its polymerization rate, significantly influences biological and mechanical properties that allow the establishment of an elastic, strong and flexible tridimensional membrane, capable of supporting and directing more efficiently stem cell migration, cytokine incorporation and wound healing process. Structural strength of the L-PRF membrane allows handling and suture on the application site (Dohan Ehrenfest et al.).

By in vitro experiments Tsai et al. (2009), assessed the effects of L-PRF on periodontally related cells. They found that PRF membrane may modulate cell proliferation in a cell type-specific manner by stimulating osteoblast, gingival fibroblasts and periodontal ligament cells growth but retarding epithelial cell proliferation. This retard is important for periodontal regeneration because it might avoid epithelium interference with new attachment formation on root surfaces.

Aroca et al. (2009) combined a PRF membrane with a modified coronally advanced flap and concluded that an inferior root coverage was observed after six months. In the Journal of Periodontology section "Letters to the Editor", Del Corso et al. (2009) wrote important comments related with Aroca's job published in the same journal. He highlights the importance of understanding clinical practice with the fibrin biomaterial biologic knowledge. Del Corso et al. inquired about membrane preparation and conservation in an attempt to clarify how these variables can influence PRF matrix structural characteristics and growth factor content to ensure favorable clinical results in terms of root coverage. Red blood cells separation, membrane number for surgical site and membrane adequate positioning are some of the critical points Del Corso et al. highlights to use these PRF membranes adequately during periodontal surgery. In conclusion, it is necessary to understand that PRF biomaterial require a wellconsidered adapted clinical methodology.

In a case report made by Anilkumar et al. (2009), they proved that six months after use a laterally repositioned flap in combination with PRF to cover a localized recession in the buccal side of a mandibular incisor, complete root coverage was achieved with excellent tissue contour and color, a proof that this fibrin biomaterial has potential for being used in periodontal surgeries. 
Fan et al. (2013) studied the biological behavior (proliferation, migration and expression of collagen I) of human gingival fibroblasts with PRF. Fibroblasts were cocultured with PRF autologous membranes, and cytotoxicity and cell proliferation were assessed by MTT assay. They found that PRF increase gingival fibroblasts proliferation over time. Migration assays and collagen I values were also significantly higher than control group. They conclude that PRF can have a positive effect on human gingival fibroblasts biological behavior and that it has clinical application potential for gingival recession treatment and periodontal tissue engineering.

Thamaraiselvan et al. (2015) determined that the addition of an autologous platelet rich fibrin membrane to a coronally advanced flap provided no added advantage in terms of root coverage in cases of adjacent recession defects treatment. Rajaram et al. (2015) evaluated the effect of PRF in conjunction with double lateral sliding bridge flap and found that it gives no additional benefits to the clinical parameters measured in root coverage.

Multiple alternatives have been developed to find root coverage better results, avoiding the need from a donor site additional intervention that often has unpleasant patient effects such as pain and bleeding risk. L-PRF has been studied as an alternative to avoid the second donor site and as a tissue healing cellular response enhancer. This first approach of the combination of cultured cells (autologous gingival fibroblasts) and a plasma component (L-PRF), demonstrates that tissue engineering can develop laboratory techniques useful for clinical application in periodontics. This study sought to evaluate clinical parameters (MG-UAC / MG-UMG) in root coverage, using a conventional surgical technique for recipient bed preparation and to reduce plasma donation to a few milliliters and $3 \mathrm{~mm}$ of keratinized mucosa.

Clinical results showed a significant gain measurement of the MG-UAC (Table I) at 6-months, compared to the initial measurements in 4 of the $5 \mathrm{ca}-$ ses. Probably, local conditions in the case that did not show root surface coverage could be associated to the position of the radicular eminence outside the perimeter of the alveolar bone. The highest coverage of the radiating surface obtained in case 5 (in millimeters), was achieved with $3 \mathrm{~mm}$ of coverage. In this patient, periodontal biotype was different from the other 4 cases; presented a thick periodontium that favors the obtained result in periodontal plastic surgery techniques that look for the radicular cover. With regard to the amount of keratinized mucosa, no gain was achieved (Table II). In one of the cases $1 \mathrm{~mm}$ was lost at 6 months; in the other recessions, no loss and no gain of keratinized mucosa were recorded.

In one case, there was evidence of change in the position of the gingival margin in a neighboring tooth, an associated phenomenon to a failure in the execution of the surgical technique when a perforation was presented in the $2 \mathrm{~mm}$ mucosa that resulted in 1 $\mathrm{mm}$ apical healing at the gingival margin of the same tooth. In general, those who agreed to participate in the study showed an interest in reducing post-operative morbidity by reducing the intervention of the conventional donor site.

Table I. Patients characteristics included in the study.

\begin{tabular}{cccc}
\hline Patient & Age & Sex & Medical Condition \\
\hline 1 & 51 & Female & Healthy \\
2 & 36 & Female & Healthy \\
3 & 35 & Female & Healthy \\
4 & 50 & Male & Healthy \\
5 & 65 & Female & Hypertension, Psoriasis, Sinusitis. \\
\hline
\end{tabular}

Table II. Measurement from gingival margin (MG) to the cement-enamel junction (CEJ) from the most apical point.

\begin{tabular}{cccc}
\hline Patient & $\begin{array}{c}\text { Measurement } \\
0(\mathrm{~mm})\end{array}$ & $\begin{array}{c}\text { 3 Month } \\
\text { Measurement }(\mathrm{mm})\end{array}$ & $\begin{array}{c}6 \text { Month } \\
\text { Measurement }(\mathrm{mm})\end{array}$ \\
\hline 1 & 3 & 2 & 2 \\
2 & 5 & 2 & 3 \\
3 & 5 & 2 & 3 \\
4 & 5 & 5 & 5 \\
5 & 7 & 3 & 4 \\
\hline
\end{tabular}


Table III. Measurement of the gingival margin (MG) to the mucogingival junction (MGJ).

\begin{tabular}{cccc}
\hline Patient & $\begin{array}{c}\text { Measurement } 0 \\
(\mathrm{~mm})\end{array}$ & $\begin{array}{c}\text { 3 Month Measurement } \\
(\mathrm{mm})\end{array}$ & $\begin{array}{c}6 \text { Month Measurement } \\
(\mathrm{mm})\end{array}$ \\
\hline 1 & 2 & 2 & 2 \\
2 & 1 & 1 & 1 \\
3 & 1 & 1 & 1 \\
4 & 1 & 0 & 0 \\
5 & 4 & 4 & 4
\end{tabular}

\section{CONCLUSION}

A combined technique to treat adjacent recession defects with L-PRF membranes and autologous oral mucosa fibroblasts in a coronal displaced flap did not show initial advantage compared with a gold standard surgery that includes an autologous soft tissue graft. Nevertheless, it could be an alternative for clinical application if an appropriate technical protocol and a standardized clinical technique warrants a proper management of this new biomaterial. More clinical evidence is needed to prove their true benefits.

The results obtained, cannot be compared with those of other conventional techniques for root coverage, by the individual characteristics of each case and the lack of a significant population of L-PRF combined with fibroblasts. The initial results show that tissue healing benefits can be achieved with more userfriendly postoperative procedures, but actual clinical benefit does not approximate the obtained by coronal displacement of a flap plus the attachment of a connective tissue graft.

\section{ACKNOWLEDGEMENTS}

The authors thanks to the IPS Universitaria Research Center, the Periodontic Service and the Medicine Faculty from the University of Antioquia. Partial funding for this research has been received from the Colombian Government Royalties Program.

MERIZALDE, G.; LOPERA, D.; VILLEGAS, M. \& RESTREPO, L. M. Fibrina rica en plaquetas leucocitarias con fibroblastos gingivales autólogos en el tratamiento de defectos de recesión adyacentes. Int. J. Odontostomat., 13(1) 23-30, 2019.

RESUMEN: El periodonto puede presentar cambios que conducen a la pérdida de integridad, como la enfermedad periodontal, los trastornos inmunes o el cepillado traumático. Una de las consecuencias más comunes que resultan de estos eventos es la migración apical del tejido marginal gingival. Entre los biomateriales utilizados para la regeneración del tejido periodontal, las matrices de fibrina han recibido una atención significativa para corregir las recesiones gingivales. Se extrajeron cinco biopsias de mucosa oral, los fibroblastos se cultivaron in vitro y se congelaron en nitrógeno líquido. Tres tubos de vidrio estériles de $10 \mathrm{ml}$ se llenaron con sangre del paciente y se centrifugaron inmediatamente. Los coágulos fueron extraídos y comprimidos para obtener membranas de L-PRF. Se agregaron fibroblastos autólogos de mucosa oral a las membranas y se realizaron procedimientos quirúrgicos en cinco pacientes. El tamaño de poro de la red de fibrina L-PRF era demasiado pequeño para permitir la penetración de los fibroblastos humanos, pero estaban firmemente unidos a la superficie de la membrana. Se usaron fibroblastos gingivales de cultivos de células frescas y recientemente descongelados para unirlos a las membranas L-PRF. Fue posible establecer un protocolo para la extracción de sangre, centrifugación, compresión de coágulos de fibrina, adhesión de fibroblastos a la superficie de la membrana y aplicación al paciente en un tiempo relativamente corto (1 hora, 1 hora y 30 minutos). Dos pacientes expresaron síntomas de dolor y los otros presentaron hinchazón leve sin dolor. En la primera semana, el tejido adyacente mostró pocos signos de inflamación. Se están realizando esfuerzos de investigación para desarrollar técnicas quirúrgicas más conservadoras y nuevos biomateriales que puedan promover la proliferación celular. Debido a sus propiedades, las membranas L-PRF representan una alternativa tentadora. Una técnica combinada para tratar los defectos de recesión adyacentes con membranas de L-PRF y fibroblastos de mucosa oral autóloga en un colgajo coronal desplazado no mostró una ventaja inicial en comparación con una cirugía estándar que incluye un injerto de tejido blando autólogo. Sin embargo, podría ser una alternativa para la aplicación clínica como un nuevo biomaterial de células funcionales. Se necesita más evidencia clínica.

PALABRAS CLAVE: fibrina, periodonto, fibroblastos, cicatrización de heridas, recesión gingival. 


\section{REFERENCES}

Anilkumar, K.; Geetha, A.; Umasudhakar; Ramakrishnan, T.; Vijayalakshmi, R. \& Pameela, E. Platelet-rich-fibrin: A novel root coverage approach. J. Indian Soc. Periodontol., 13(1):504, 2009.

Aroca, S.; Keglevich, T.; Barbieri, B.; Gera, I. \& Etienne, D. Clinical evaluation of a modified coronally advanced flap alone or in combination with a platelet-rich fibrin membrane for the treatment of adjacent multiple gingival recessions: a 6-month study. J. Periodontol., 80(2):244-52, 2009.

Buti, J.; Baccini, M.; Nieri, M.; La Marca, M. \& Pini-Prato, G. P. Bayesian network meta-analysis of root coverage procedures: ranking efficacy and identification of best treatment. J. Clin. Periodontol., 40(4):372-86, 2013.

Clark, R. A. Fibrin and wound healing. Ann. N. Y. Acad. Sci., 936:355-67. 2001.

Danielsen, P.; Jørgensen, B.; Karlsmark, T.; Jorgensen, L. N. \& Agren, M. S. Effect of topical autologous platelet-rich fibrin versus no intervention on epithelialization of donor sites and meshed split-thickness skin autografts: a randomized clinical trial. Plast. Reconstr. Surg., 122(5):1431-40, 2008.

Del Corso, M.; Sammarino, G. \& Dohan Ehrenfest, D. M. Letter to the Editor: Re: "Clinical Evaluation of a Modified Coronally Advanced Flap Alone or in Combination With a Platelet-Rich Fibrin Membrane for the Treatment of Adjacent Multiple Gingival Recessions: A 6-Month Study". J. Periodontol., 80(11):1694-7, 2009.

Dohan Ehrenfest, D. M.; Del Corso, M.; Diss, A.; Mouhyi, J. \& Charrier, J. B. Three-dimensional architecture and cell composition of a Choukroun's platelet-rich fibrin clot and membrane. J. Periodontol., 81(4):546-55, 2010.

Fan, W. J.; Yang, M.; Zhang, C.; Xue, R.; Zhang, W. \& Qin, H. X. Effects of Choukroun's platelet-rich fibrin on humangingival fibroblasts proliferation, migration and type I collagen secretion. Zhonghua Kou Qiang Yi Xue Za Zhi, 48(2):72-6, 2013.

Feng, Z. \& Weinberg, A. Role of bacteria in health and disease of periodontal tissues. Periodontol. 2000, 40:50-76, 2006

Miller, P. D. Jr. A classification of marginal tissue recession. Int. J. Periodontics Restorative Dent., 5(2):8-13, 1985.

Pini Prato, G. Mucogingival deformities. Ann. Periodontol., 4(1):98$101,1999$.

Rajaram, V.; Thyegarajan, R.; Balachandran, A.; Aari, G. \& Kanakamedala, A. Platelet Rich Fibrin in double lateral sliding bridge flap procedure for gingival recession coverage: An original study. J. Indian Soc. Periodontol., 19(6):665-70, 2015.

Ramachandra, S. S.; Rana, R.; Reetika, S. \& Jithendra, K. D. Options to avoid the second surgical site: a review of literature. Cell Tissue Bank., 15(3):297-305, 2014.

Sonick, M. \& Hwang, D. The dependability of connective tissue grafting for the resolution of full-mouth recession. Compend. Contin. Educ. Dent., 32(1):48-53. 2011

Thamaraiselvan, M.; Elavarasu, S.; Thangakumaran, S.; Gadagi, J. S. \& Arthie, T. Comparative clinical evaluation of coronally advanced flap with or without platelet rich fibrin membrane in the treatment of isolated gingival recession. J. Indian Soc. Periodontol., 19(1):66-71, 2015.

Thoma, D. S.; Benic', G. I.; Zwahlen, M.; Hämmerle, C. H. \& Jung, R. E. A systematic review assessing soft tissue augmentation techniques. Clin. Oral Implants Res., 20 Suppl. 4:146-65, 2009.

Tobita, M. \& Mizuno, H. Adipose-derived stem cells and plateletrich plasma: the keys to functional periodontal tissue engineering. Curr. Stem Cell Res. Ther., 8(5):400-6, 2013.
Toffler, M.; Toscano, N.; Holtzclaw, D.; Corso, M. D. \& Ehrenfest, D. D. Introducing Choukroun's platelet rich fibrin (PRF) to the reconstructive surgery milieu. J. Implant. Adv. Clin. Dent., 1(6):21-30, 2009.

Tsai, C. H.; Shen, S. Y.; Zhao, J. H. \& Chang, Y. C. Platelet-rich fibrin modulates cell proliferation of human periodontally related cells in vitro. J. Dent. Sci., 4(3):130-5, 2009.

Zucchelli, G. \& De Sanctis, M. Treatment of multiple recessiontype defects in patients with esthetic demands. J. Periodontol., 71(9):1506-14, 2000.

Corresponding author:

Grupo Ingeniería de Tejidos y Terapias Celulares

Universidad de Antioquia

Medellín

COLOMBIA

Email: grupoingenieriadetejidos@udea.edu.co

Received: 27-06-2018

Accepted: 17-10-2018 